\title{
Functional reconstitution of a purified proline permease from Candida albicans: interaction with the antifungal cispentacin
}

\author{
Deepa Jethwaney, ${ }^{1} \dagger$ Milan Höfer, ${ }^{2}$ Raj K. Khaware ${ }^{1}$ \\ and Rajendra Prasad'
}

School of Life Sciences, Jawaharlal Nehru University, New Delhi110067, India

2 Botanisches Institut, Universităt Bonn, Kirschallee 1, D-53115 Bonn, Germany
Author for correspondence: Rajendra Prasad. Tel: +91 116170016. Fax: +91 116165886. e-mail: rajendra@jnuniv.ernet.in
We have purified proline permease to homogeneity from Candida albicans using an L-proline-linked agarose matrix as an affinity column. The eluted protein produced two bands of 64 and $67 \mathrm{kDa}$ by SDS-PAGE, whereas it produced a single band of $67 \mathrm{kDa}$ by native PAGE and Western blotting. The apparent $K_{m}$ for L-proline binding to the purified protein was $153 \mu \mathrm{M}$. The purified permease was reconstituted into proteoliposomes and its functionality was tested by imposing a valinomycin-induced membrane potential. The main features of L-proline transport in reconstituted systems, viz. specificity and sensitivity to $\mathrm{N}$-ethylmaleimide, were very similar to those of intact cells. The antifungal cispentacin, which enters $\mathbf{C}$. albicans cells via an inducible proline permease, competitively inhibited the L-proline binding and translocation in reconstituted proteoliposomes. However, the uptake of Lproline in proteoliposomes reconstituted with the purified protein displayed monophasic kinetics with an apparent $K_{m}$ of $40 \mu \mathrm{M}$.

Keywords: L-proline, amino acid transport, proteoliposomes, cispentacin, Candida albicans

\section{INTRODUCTION}

Among several factors which affect yeast to mycelial transition of the pathogenic pleiomorphic yeast Candida albicans, various nutrients (sugars, amino acids, and other nitrogen sources, etc.) play an important role (Odds, 1988; Shepherd, 1991). Amino acids which enter metabolism by their conversion to 2-oxoglutarate are generally more active in inducing germ tube formation in C. albicans (Shepherd, 1991). L-Proline, one such amino acid, is known to be an efficient germ tube stimulator. Hence, earlier studies encompassing the characterization of transport of L-proline have regained importance (Jayakumar et al., 1978, 1979, 1981; Dabrowa \& Howard, 1981; Holmes \& Shepherd, 1987). It has been established that the electrochemical gradient of protons generated by the plasma membrane (PM) ATPase of C. albicans is the main

†Present address: Gargi College, Delhi University, New Delhi-110049, India.

Abbreviations: AZA, azetidine-2-carboxylic acid; CCCP, carbonyl cyanide m-chlorophenylhydrazone; CM, crude membrane; DHP, 2,4-dehydro-DLproline; NEM, $\mathrm{N}$-ethylmaleimide; PM, plasma membrane. driving force for the uptake and intracellular accumulation of L-proline as well as of other amino acids (Prasad, 1987).

The kinetics of proline transport in Saccharomyces cerevisiae have revealed that the uptake of proline occurs through two pathways; via a general amino acid permease which mediates the uptake of a wide variety of $\mathrm{D}$ and $\mathrm{L}$ amino acids including $\mathrm{L}$-proline (Lasko \& Brandriss, 1981), and via a specific permease possessing a high affinity for proline (Grenson et al., 1970). In C. albicans, the transport of proline is mediated by an inducible system, which is rather unique, since no other amino acid transporter in yeast has so far been shown to elicit inducibility (Jayakumar et al., 1978, 1979, 1981; Dabrowa \& Howard, 1981; Holmes \& Shepherd, 1987).

Notwithstanding the importance of membrane transport in the overall physiology of C. albicans and in drug design, very limited knowledge of its transporters exists (Prasad, 1987; Cooper, 1982; Payne \& Shallow, 1985; Naider \& Becker, 1990). Although none of the permease or membrane proteins mediating amino acid transport have been isolated and purified from yeast, a few permease-specific genes have been cloned and sequenced 
from S. cerevisiae (Schmidt et al., 1994 and references therein). The gene responsible for basic amino acid transport in C. albicans has also recently been cloned by functional complementation of the can1 mutant of $S$. cerevisiae (Sychrova \& Chevallier, 1993). CAN1 of C. albicans has an ORF of 1713 nucleotides, encoding a protein of 571 amino acids with a calculated molecular mass of $63.3 \mathrm{kDa}$ (Sychrova \& Souciet, 1994). Generally, the size of yeast amino acid transport permeases deduced from their primary structures ranges between 64 and $68 \mathrm{kDa}$. The amino acid sequence of the permeases displays a high degree of hydrophobicity with 10-12 membrane-spanning stretches (Schmidt et al., 1994).

To understand the functional processes of specific amino acid transporters, it is, however, essential that the protein in question is isolated and purified in its active form from the native membranes. The lack of an easy binding assay and the low amount of these transport proteins in the PM, coupled with their extreme hydrophobicity, have so far severely hampered attempts to purify them. For the first time we have succeeded in purifying an L-proline permease from $C$. albicans to homogeneity in a single step by using affinity chromatography. The assessment of the characteristics of Lproline binding to the purified protein and of its uptake kinetics into reconstituted proteoliposomes is the subject of this paper.

\section{METHODS}

Strain, growth conditions and materials. Candida albicans strain ATCC 10261 was grown and cultured in YEPD medium ( $2 \%$ peptone, $1 \%$ yeast extract and $2 \%$ glucose) (Rao et al., 1986; Prasad \& Höfer, 1987).

L-Proline agarose and Tween 40 were from Sigma. L$\left[{ }^{14} \mathrm{C}\right]$ Proline (specific activity $9.250 \mathrm{GBq} \mathrm{mmol}^{-1}$ ) was from Bhabha Atomic Research Center. All other reagents and chemicals of the highest purity grade were procured from local resources.

Transport of L-proline in the intact cells. Transport of Lproline was assayed as described in our earlier publications (Jayakumar et al., 1978, 1979, 1981).

Isolation of the crude membrane (CM). Cells grown to midexponential phase in YEPD medium ( $1 \mathrm{~g}$ wet wt) were suspended in $2 \mathrm{ml}$ grinding medium $(250 \mathrm{mM}$ sucrose, $10 \mathrm{mM}$ Tris/ $\mathrm{HCl}, \mathrm{pH} 7 \cdot 5,1 \mathrm{mM}$ PMSF) and $2 \mathrm{~g}$ glass beads $(0.45-0.50 \mathrm{~mm}$ diameter $)$. The suspension was mechanically disrupted in an MSK Braun cell homogenizer by agitating it for a total of nine cycles of $5 \mathrm{~s}$ each at 4000 vibrations $\mathrm{min}^{-1}$. The homogenate was collected and centrifuged at $1000 \mathrm{~g}$ for 5 min at $4{ }^{\circ} \mathrm{C}$ to remove unbroken cells and glass beads. The supernatant was then centrifuged for $40 \mathrm{~min}$ at $15000 \mathrm{~g}$ at $4^{\circ} \mathrm{C}$ and the resulting $\mathrm{CM}$ pellet was resuspended in $10 \mathrm{mM}$ Tris $/ \mathrm{HCl}(\mathrm{pH} 7 \cdot 5)$. The $\mathrm{CM}$ fraction was stored at $-70^{\circ} \mathrm{C}$ until further use.

Isolation of the purified PM fraction. The CM fraction was diluted with Percoll $(18 \%, \mathrm{v} / \mathrm{v})$ in $10 \mathrm{mM}$ Tris $/ \mathrm{HCl}(\mathrm{pH} 7 \cdot 5)$. The suspension was centrifuged at $40000 \mathrm{~g}$ for $40 \mathrm{~min}$ at $4{ }^{\circ} \mathrm{C}$ in a Sorvall TH-641 rotor (Hubbard et al., 1986). The gradient so obtained had a translucent lipid layer on the top and a PM band just below it. The PM was aspirated and washed twice with $10 \mathrm{mM}$ Tris $/ \mathrm{HCl}(\mathrm{pH} 7 \cdot 5)$ by centrifugation at $100000 \mathrm{~g}$ for $30 \mathrm{~min}$ in the same rotor to remove traces of Percoll. The purified PM pellet was resuspended in $10 \mathrm{mM}$ Tris/ $\mathrm{HCl}$ ( $\mathrm{pH} 7 \cdot 5$ ) and the purity of the PM was routinely checked by assaying $\mathrm{H}^{+}$-ATPase at $\mathrm{pH} 6.6$ and 9.0 (optimum $\mathrm{pH}$ for mitochondrial ATPase). The ratio of the two activities $(P=$ $\left.R_{6 \cdot 6} / R_{9 \cdot 0}\right)$ was always high $(>30)$, implying almost no contamination by the mitochondrial fraction (Gupta et al., 1991).

Solubilization and purification of L-proline permease. The purified PM in a total volume of $3 \mathrm{ml}\left(3-4 \mathrm{mg}\right.$ protein $\mathrm{ml}^{-1}$ ) was solubilized using Tween $40(0.7 \%, v / v)$ as a detergent in the solubilization buffer containing $10 \mathrm{mM} \mathrm{Tris} / \mathrm{HCl}$ (pH 7.5), $1 \mathrm{mM}$ PMSF, $1 \mathrm{mM}$ EDTA and $2 \mathrm{mM}$ 2-mercaptoethanol. The samples were incubated at $30^{\circ} \mathrm{C}$ for $5 \mathrm{~min}$ and then sonicated for $3-4 \mathrm{~min}$ in a bath sonicator (Julabo, Seelbach) at $30^{\circ} \mathrm{C}$. The solubilized proteins $(7-10 \mathrm{ml})$ were separated from the unsolubilized protein by centrifugation at $40000 \mathrm{~g}$ for $30 \mathrm{~min}$ in a Sorvall centrifuge using a TH-641 rotor. The soluble protein present in the supernatant was dialysed for $12 \mathrm{~h}$ against $10 \mathrm{mM}$ Tris/ $\mathrm{HCl}(\mathrm{pH} 7 \cdot 5)$ to remove additives like PMSF, EDTA and 2-mercaptoethanol. The dialysis also resulted in the partial removal of the detergent; however, the detergent concentration remained above its critical micellar concentration value and the solubilized protein stayed in solution. The dialysed protein fraction (7-8 mg) was loaded onto an L-proline-linked agarose column $(5 \mathrm{ml})$ equilibrated with $100 \mathrm{mM}$ Tris/citrate $(\mathrm{pH} \mathrm{5.5)}$ containing $0.1 \%$ Tween 40 . The unbound protein was eluted with 10 bed volumes $(50 \mathrm{ml})$ of this buffer. The bound protein was then eluted with 3-4 bed volumes $(20-25 \mathrm{ml}) 2 \mathrm{M} \mathrm{NaCl}$ (containing $0 \cdot 1 \%$ Tween 40 ). Each eluted fraction of $5 \mathrm{ml}$ was dialysed for $12 \mathrm{~h}$ against $10 \mathrm{mM}$ Tris $/ \mathrm{HCl}\langle\mathrm{pH} \mathrm{7.5 \rangle}$ to remove $\mathrm{NaCl}$ before the binding assay.

Equilibrium dialysis for the binding assay. In order to monitor the purification of proline permease, it was essential to develop a reliable assay. Using the Dianorm equilibrium dialysis system, it was possible to do several binding assays simultaneously. L-Proline binding to CM, PM and purified protein was done routinely using equilibrium dialysis. The two teflon chambers of each dialyser unit were separated by dialysis membrane with a 1000 Da cut-off (no. 10.16; Dianorm) which was earlier soaked in $10 \mathrm{mM}$ Tris/citrate ( $\mathrm{pH} \mathrm{5.5)}$ for $5 \mathrm{~min}$. One of the chambers was filled with membrane protein (200 $\mu \mathrm{g} \mathrm{CM}$ or PM or $1-2 \mu \mathrm{g}$ purified protein), $100 \mathrm{mM}$ Tris/citrate (pH 5.5) and $10 \mu \mathrm{M}$ (unless otherwise mentioned) $\mathrm{L}-\left[{ }^{14} \mathrm{C}\right]$ proline $\left(925 \mathrm{MBq} \mathrm{mmol}^{-1}\right)$ in a total volume of $1 \mathrm{ml}$; the other chamber contained only buffer $(100 \mathrm{mM} \mathrm{Tris} / \mathrm{HCl}$, $\mathrm{pH} 5.5)$. The dialyser unit was submerged in a $30^{\circ} \mathrm{C}$ waterbath and rotated at 12 r.p.m. for $12-14$ h. The solutions were collected from each chamber and the radioactivity of a $10 \mu \mathrm{l}$ aliquot was counted by using a Beckman beta liquid scintillation counter with a detergent-based scintillation cocktail. The binding was calculated from the difference in c.p.m. obtained between the two chambers after equilibrium dialysis. The difference in c.p.m. between the two chambers was very reproducible between different sets of experiments. The variation between different values was never more than $5 \%$.

Evaluation of the binding assay. The concentration of bound ligand was calculated as follows. At equilibrium at $30^{\circ} \mathrm{C}$, the value $L_{\mathrm{f}}$ (final concentration of free ligand) is the same on both sides of the dialysis membrane. Hence

$L_{0}=L_{\mathrm{f}}+L_{\mathrm{p}}+L_{\mathrm{b}}$ 
where $L_{0}$ is the initial concentration of ligand and $L_{\mathrm{b}}$ is the concentration of bound ligand.

Therefore

$L_{\mathrm{p}}=L_{0}-2 L_{\mathrm{f}}$

Protein gel electrophoresis. Protein gel electrophoresis was performed as described by Laemmli (1970) and O'Farrel (1975). The separated proteins were visualized by the silver staining method of Blum et al. (1987). The native polyacrylamide gel was run in a similar manner without the addition of SDS and 2-mercaptoethanol.

Polyclonal antiserum. Polyclonal antiserum against the purified protein was raised in 5-7-month-old healthy rabbits. A bulk quantity of proline permease was purified from $C$. albicans. The aliquot from the sample was checked for homogeneity as well as for binding activity. The pure homogeneous protein sample $(50-100 \mu \mathrm{g})$ suspended in PBS $(0.145 \mathrm{M} \mathrm{NaCl} ; 0.15 \mathrm{M}$ sodium phosphate) was injected in the rabbits with the help of Freund's adjuvant. Two further boosters of immunogen $(50 \mu \mathrm{g}$ protein in PBS) were injected after every $10 \mathrm{~d}$. The rabbits were bled a week after the last booster injection and the polyclonal antiserum was prepared from it. The specificity of the antiserum was determined by an ELISA and also by immunostaining of the electroblots (Catty \& Raykundalia, 1988).

Protein estimation. Protein estimations were done using the Bradford (1976) method. Since the detergents used for solubilization of membrane proteins interfered with the Bradford assay, proteins were also estimated by the Lowry method and by measuring the $A_{280}$. The results of the protein estimation by different methods were compatible.

Reconstitution of purified proline permease into proteoliposomes. The proteoliposomes were reconstituted using a detergent-dialysis procedure as described by Höfer and co-workers (Mair \& Höfer, 1988; Höfer et al., 1991). Egg phosphatidylcholine $\left(20 \mathrm{mg} \mathrm{ml}^{-1}\right)$ and $40 \mathrm{mg} n$-octyl $\beta$-D-glucopyranoside (molar phospholipid to detergent ratio $=0.5$ ) were dissolved in $1 \mathrm{ml}$ ethanol. The solution was evaporated to dryness in a vacuum evaporator by slowly rotating the evaporation flask. One millilitre of purified protein $(1-2 \mu \mathrm{g})$ in reconstitution buffer containing $50 \mathrm{mM}$ Tris/citrate (pH 4.5), $25 \mathrm{mM} \mathrm{K}_{2} \mathrm{SO}_{4}$ and $5 \mathrm{mM} \mathrm{MgSO}_{4}$ was added to the phospholipid-detergent film and the flask was again rotated without applying vacuum until the solution became clear. The phospholipid-detergent solution was transferred into the 'Mini-Lipoprep' dialysis apparatus (Dianorm) and dialysed for $2 \mathrm{~h}$ (with a single change after $1 \mathrm{~h}$ ) at $15^{\circ} \mathrm{C}$ against 0.51 reconstitution buffer using a dialysis membrane with a $1000 \mathrm{Da}$ cut-off (no. 10.16; Dianorm). Reconstitution of proteoliposomes was completed after $2 \mathrm{~h}$. To remove extravesicular $\mathrm{K}^{+}$from the suspension of proteoliposomes, dialysis continued for a further $30 \mathrm{~min}$ against a fresh reconstitution buffer containing $25 \mathrm{mM} \mathrm{Na}_{2} \mathrm{SO}_{4}$ instead of $\mathrm{K}_{2} \mathrm{SO}_{4}$. This step significantly improved the energization of proteoliposomes upon the addition of valinomycin.

Measurement of $\mathrm{L}-\left[{ }^{14} \mathrm{C}\right]$ proline uptake in the reconstituted proteoliposomes. The uptake of L-proline in reconstituted proteoliposomes was initiated by adding $100-150 \mu \mathrm{l}$ proteoliposome suspension to the reaction mixture (total volume $1.0 \mathrm{ml}$ ) composed of $50 \mathrm{mM}$ Tris/citrate $(\mathrm{pH} 4.5), 5 \mathrm{mM}$ $\mathrm{MgSO}_{4}, 10 \mu \mathrm{M}$ valinomycin (added after $60 \mathrm{~s}$ ) and $10-100 \mu \mathrm{M}$ $\mathrm{L}-\left[{ }^{14} \mathrm{C}\right]$ proline at $30^{\circ} \mathrm{C}$. Aliquots of $100 \mu \mathrm{l}$ of the reaction mixture at particular time periods were withdrawn and filtered through a nitrocellulose membrane filter $(0.45 \mu \mathrm{m}$ pore size; Sartorius). The filters were washed twice with $3 \mathrm{ml}$ of the cold buffer $\left(10 \mathrm{mM}\right.$ Tris/citrate, $\mathrm{pH} 4 \cdot 5$, and $\left.5 \mathrm{mM} \mathrm{MgSO}_{4}\right)$, con- taining the same concentration of unlabelled L-proline. The filters were then transferred into the scintillation cocktail and the amount of radioactivity retained in the proteoliposomes was measured using a Beckman beta liquid scintillation counter.

\section{RESULTS}

Functional reconstitution of symporters in yeast has so far been achieved mainly by using PM vesicles fused to proteoliposomes (Cooper, 1982; Höfer et al., 1991; Serrano, 1988; Wach et al., 1990). However, in this work, we have for the first time functionally reconstituted a purified proline permease protein of $C$. albicans.

\section{Solubilization and purification of the proline permease}

Purified PM was solubilized using Tween 40 , which was able to solubilize more than $80 \%$ of the total membrane protein, and then loaded onto the L-proline-linked agarose matrix column equilibrated with washing buffer $\langle 0.1 \%$ Tween 40 in $100 \mathrm{mM}$ Tris/citrate, $\mathrm{pH} 5.5)$. At this $\mathrm{pH}$, proline permease showed maximum binding when checked with the equilibrium dialysis assay (Fig. $2 \mathrm{~d})$. The bound protein was eluted by the addition of $2 \mathrm{M} \mathrm{NaCl}$ containing $0.1 \%$ Tween 40 and each $5 \mathrm{ml}$ fraction was analysed for L-proline binding. Out of five fractions, only the third fraction gave maximum binding with L-proline (Fig. 1). Various structural analogues of

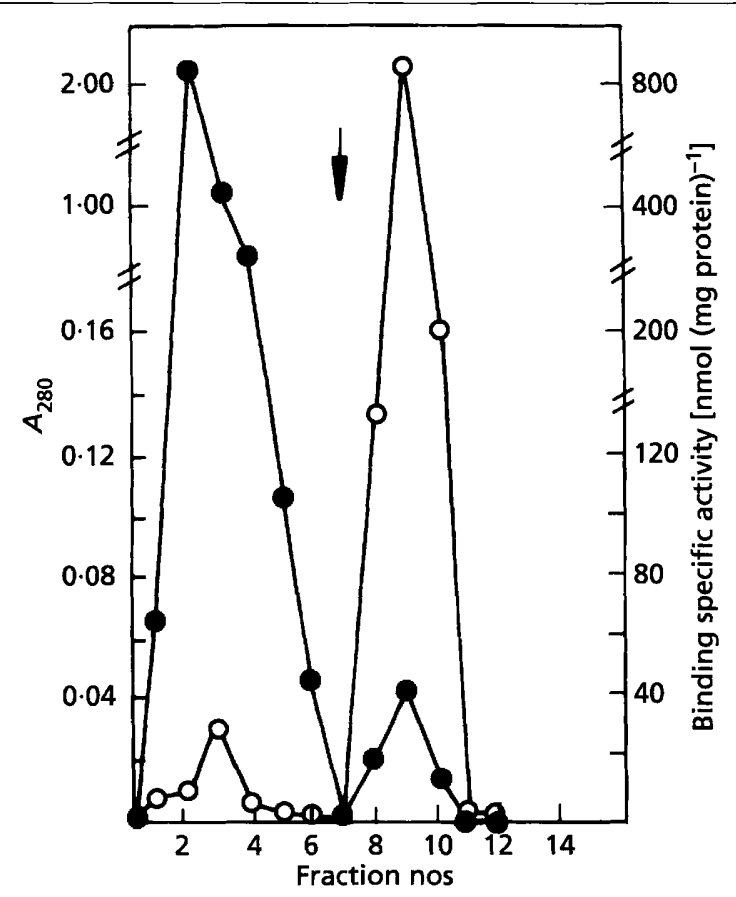

Fig. 1. Elution profile of the L-proline affinity column. Solubilized proteins were fractionated on an L-proline agarose column as described in Methods. The arrow indicates the addition of $2 \mathrm{M} \mathrm{NaCl}$ for elution of bound protein from the column. Fractions of $5 \mathrm{ml}$ were collected. The specific activity of L-proline binding $(O)$ and protein concentration $(O)$ were determined as described in Methods. 
Table 1. Purification of the proline permease by affinity chromatography

\begin{tabular}{|c|c|c|c|c|}
\hline Preparation & $\begin{array}{c}\text { Protein } \\
\left(\mathrm{mg} \mathrm{ml}^{-1}\right)\end{array}$ & $\begin{array}{c}\text { Total protein } \\
(\mathbf{m g})\end{array}$ & $\begin{array}{l}\text { Binding specific } \\
\text { activity }[\mathrm{nmol} \\
\left.(\mathrm{mg} \text { protein })^{-1}\right]^{*}\end{array}$ & $\begin{array}{c}\text { Purification } \\
\text { (-fold }) \dagger\end{array}$ \\
\hline $\mathrm{CM}$ & $4 \cdot 5$ & $36 \cdot 0$ & $8 \cdot 0$ & $1 \cdot 0$ \\
\hline PM & $3 \cdot 5$ & $10 \cdot 5$ & $10 \cdot 5$ & $1 \cdot 3$ \\
\hline Solubilized PM & $1 \cdot 0$ & $7 \cdot 0$ & $15 \cdot 0$ & $1 \cdot 9$ \\
\hline Purified protein & $0 \cdot 002$ & $0 \cdot 01$ & $860 \cdot 0$ & $107 \cdot 5$ \\
\hline
\end{tabular}

* Proline binding was measured as described in Methods. The specific activity values represent the capacity of L-proline binding when the external concentration of L-proline was $10 \mu \mathrm{M}$.

† Purification (-fold) was calculated by assuming the specific activity of binding of PM to be $1 \cdot 3$. The data are representative of a typical column run.

(a)

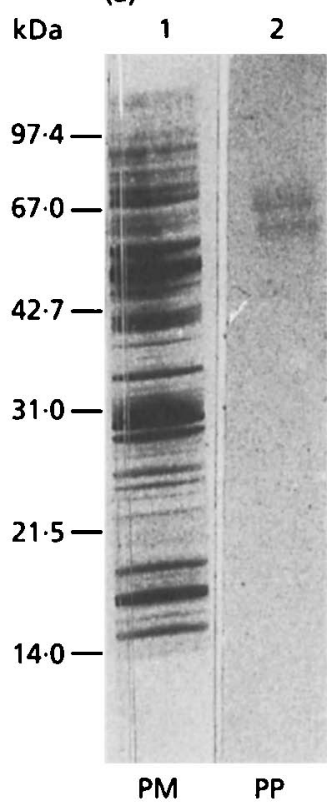

(b)

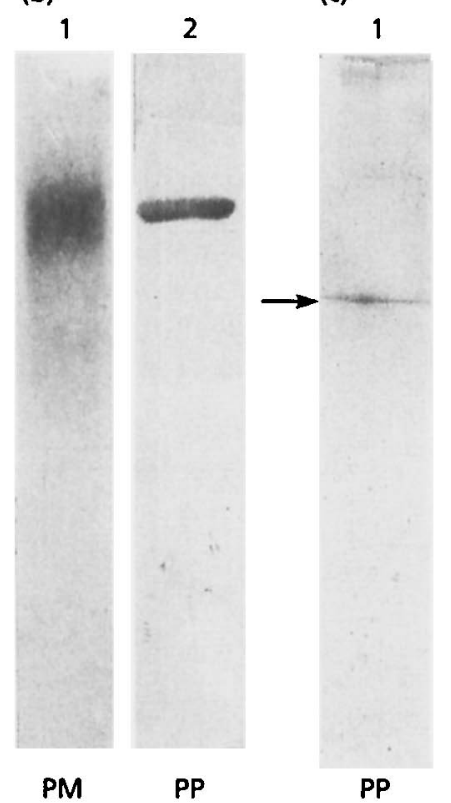

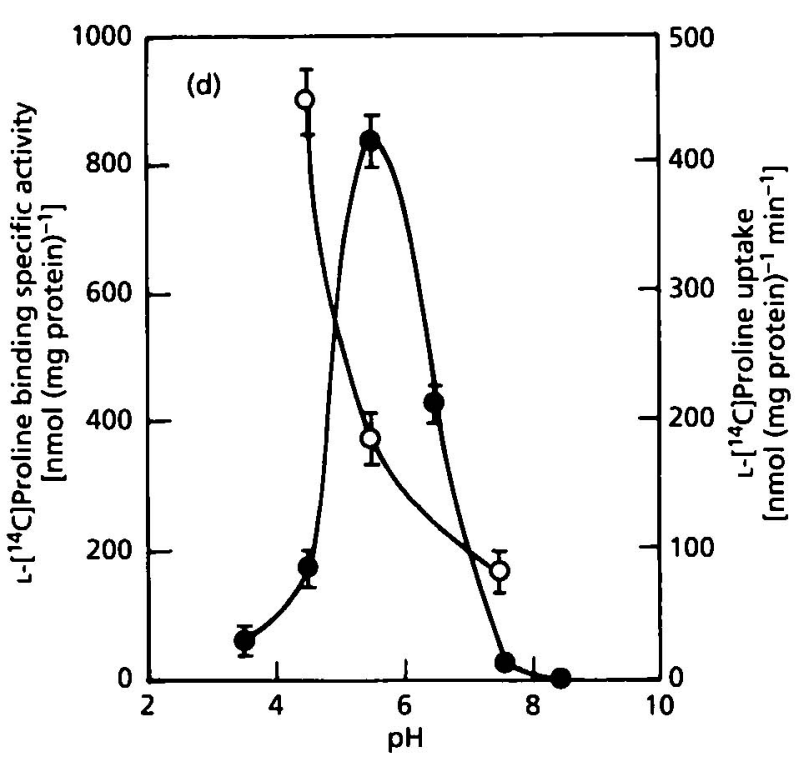

Fig. 2. SDS-PAGE of fractions at various steps of purification. (a) Lanes: $1, P M ; 2$, the purified protein fraction (PP) on a linear density gradient (6-20\%). Molecular mass standards are marked. (b) Immunodetection of purified protein on a Western blot. Lanes: 1, PM; 2 , the purified protein fraction (PP). (c) Native PAGE of the purified protein fraction on a linear gradient $(6-20 \%)$ gel. The size of the PP on the native gel $(67.0 \mathrm{kDa})$ is indicated by an arrow. (d) Specific binding of L-proline to the purified protein (O) and translocation of L-proline in reconstituted proteoliposomes $(O)$ as a function of $\mathrm{pH}$. The specific binding of L-proline and its uptake in proteoliposomes were performed as described in Methods.

L-proline, e.g. 2,4-dehydro-DL-proline (DHP) and azetidine-2-carboxylic acid (AZA), were also able to elute the bound protein but for convenience $2 \mathrm{M} \mathrm{NaCl}$ was routinely used for elution. There was more than 100 -fold enhancement of specific binding of the purified protein. The yield of the purified permease represented $0 \cdot 1 \%$ of the total PM protein (Table 1 ).

The purity of the final protein preparation was analysed by SDS-PAGE. The purified protein produced two diffuse bands of 64 and $67 \mathrm{kDa}$ (Fig. 2a). By native PAGE, however, the purified protein produced only a single band (Fig. 2c). The polyclonal antiserum raised against the purified permease also produced a single thick band on a Western blot, but it showed a dense zone between 63 and $67 \mathrm{kDa}$ in the PM fraction (Fig. 2b). LProline binding to the purified protein has a sharp optimum at $\mathrm{pH} 5 \cdot 5$. There was practically no binding beyond this $\mathrm{pH}$ (Fig. 2d). The structural analogues of $\mathrm{L}^{-}$ proline, i.e. DHP and AZA, were able to inhibit the binding competitively by more than $90 \%$ while Dproline had no significant effect. None of the other amino acids could significantly inhibit L-proline binding when applied at a 100 -fold excess concentration (Table 
Table 2. Substrate specificity of proline permease

Binding and reconstitution experiments were performed as described in Methods. $L-\left[{ }^{14} \mathrm{C}\right]$ Proline $(10 \mu \mathrm{M})$ and 100 -fold concentrations of the competitors were used in these experiments. Amino acids other than those mentioned in the Table were also tried for the competition studies but none of them could inhibit its binding nor its uptake in the reconstituted proteoliposomes. Data are arithmetic mean $\pm \mathrm{SEM}$ of three determinations.

\begin{tabular}{|c|c|c|c|c|c|c|}
\hline Substrate & $\begin{array}{l}\text { Proline uptake in } \\
\text { C. albicans } \\
\text { cells [nmol } \\
(\mathrm{mg} \text { dry } w \mathrm{t})^{-1} \mathrm{~s}^{-1} \text { ] }\end{array}$ & $\begin{array}{c}\text { Inhibition } \\
\text { of uptake } \\
(\%)\end{array}$ & $\begin{array}{c}\text { Binding specific } \\
\text { activity } \\
{[\text { nmol }(\mathrm{mg}} \\
\left.\text { purified protein })^{-1}\right]\end{array}$ & $\begin{array}{c}\text { Inhibition } \\
\text { of binding } \\
(\%)\end{array}$ & $\begin{array}{c}\text { Proline uptake in } \\
\text { reconstituted } \\
\text { proteoliposomes } \\
{[\text { nmol }} \\
\text { (mg purified } \\
\left.\text { protein })^{-1} \mathrm{~s}^{-1}\right]\end{array}$ & $\begin{array}{c}\text { Inhibition } \\
\text { of uptake } \\
(\%)\end{array}$ \\
\hline None & $9 \cdot 5 \pm 2 \cdot 0$ & - & $842 \pm 44 \cdot 5$ & - & $418 \pm 13$ & - \\
\hline DHP & $1 \cdot 0 \pm 0 \cdot 1$ & $90 \cdot 0$ & $62 \pm 22 \cdot 0$ & 93.0 & $70 \pm 10$ & $83 \cdot 3$ \\
\hline AZA & $2 \cdot 0 \pm 0 \cdot 2$ & $79 \cdot 0$ & $85 \pm 10 \cdot 0$ & $90 \cdot 0$ & $85 \pm 4$ & $80 \cdot 0$ \\
\hline L-Proline & $1 \cdot 2 \pm 0 \cdot 3$ & $88 \cdot 0$ & $70 \pm 20 \cdot 0$ & $92 \cdot 0$ & $62 \pm 15$ & $85 \cdot 0$ \\
\hline D-Proline & $9 \cdot 0 \pm 3 \cdot 0$ & $5 \cdot 0$ & $785 \pm 20 \cdot 0$ & $7 \cdot 0$ & $456 \pm 50$ & - \\
\hline
\end{tabular}

2). These results are consistent with those of L-proline uptake in intact cells (Table 2) (Jayakumar et al., 1978, 1979, 1981; Dabrowa \& Howard, 1981; Holmes \& Shepherd, 1987).

\section{Half-saturation constant of L-proline binding to purified protein}

The purified protein has an apparent $K_{\mathrm{m}}$ of $153 \mu \mathrm{M}$ for L-proline; the dissociation constant $\left(K_{\mathrm{d}}\right)$ calculated from a Scatchard plot was in the range $80-100 \mu \mathrm{M}$ (data not shown). In contrast to that of $L$-proline transport in intact cells, only monophasic binding could be detected for purified permease (Jayakumar et al., 1978, 1979, 1981; Dabrowa \& Howard, 1981; Holmes \& Shepherd, 1987). C. albicans cells have two transport systems for $L-$ proline; a high-affinity system with a $K_{\mathrm{m}}$ of $50-100 \mu \mathrm{M}$ and another one of low affinity with a $K_{\mathrm{m}}$ of about $1 \mathrm{mM}$.

\section{Effect of $\boldsymbol{N}$-ethylmaleimide (NEM) and cispentacin on proline binding}

Various energy inhibitors (orthovanadate, azide and CCCP) or the addition of ATP did not inhibit or improve L-proline binding to purified permease, respectively (data not shown); however, NEM, a thiol group blocking reagent, inhibited the binding by $75 \%$ if added during the equilibrium dialysis along with the ligand. Fig. 3(a) shows that NEM did not replace bound proline when added after the binding was complete. Moreover, L-proline as well as its analogues protected the binding site from NEM inactivation.

Recently, cispentacin (2-aminocyclopentane-1-carboxylic acid), an antifungal isolated from Bacillus cereus and Streptomyces setonii, has been shown to have anticandidal activity. Cispentacin enters C. albicans cells via both inducible proline permease and other amino acid permeases (Capobianco et al., 1993). The entry of the drug is also energy-dependent and competitively inhibited by L-proline. Therefore, it was of interest to investigate drug interaction with the purified protein. Proline binding was inhibited by $75 \%$ in the presence of the drug. Similarly to the NEM effect, if cispentacin was added after binding of L-proline was complete, it had no effect on binding activity (Fig. 3a).

\section{Reconstitution of proline permease in proteoliposomes}

The purified permease demonstrated stereospecific binding and other characteristics which were consistent with earlier studies on uptake of L-proline in C. albicans cells (Dabrowa \& Howard, 1981; Holmes \& Shepherd, 1987; Jayakumar et al., 1978, 1979, 1981). However, clear proof that it is purified proline permease lies with the fact that it can also mediate L-proline translocation in a reconstituted system. Therefore, the purified protein was reconstituted in proteoliposomes by the detergentdialysis method described by Höfer et al. (1991). We have used phosphatidylethanolamine, phosphatidylserine and total Candida membrane lipids for L-proline binding and tried different lipid to protein ratios. In all cases, a 3:1 ratio gave maximum binding. Among all the lipids, phosphatidylcholine gave maximum $(2 \cdot 5$-fold $)$ enhancement of binding. The binding activation with other lipids was between 1.5 and 2.0 -fold. Therefore, for reconstitution, only phosphatidylcholine was used. The enrichment of liposomes with purified protein could not be confirmed by SDS-PAGE. Due to the hydrophobic nature of the proteoliposomes, purified protein did not move on the gel. However, based on the specificity and kinetics of uptake of L-proline into proteoliposomes (discussed below), it was evident that the permease protein was incorporated into the liposomes in a rightside-out orientation. 


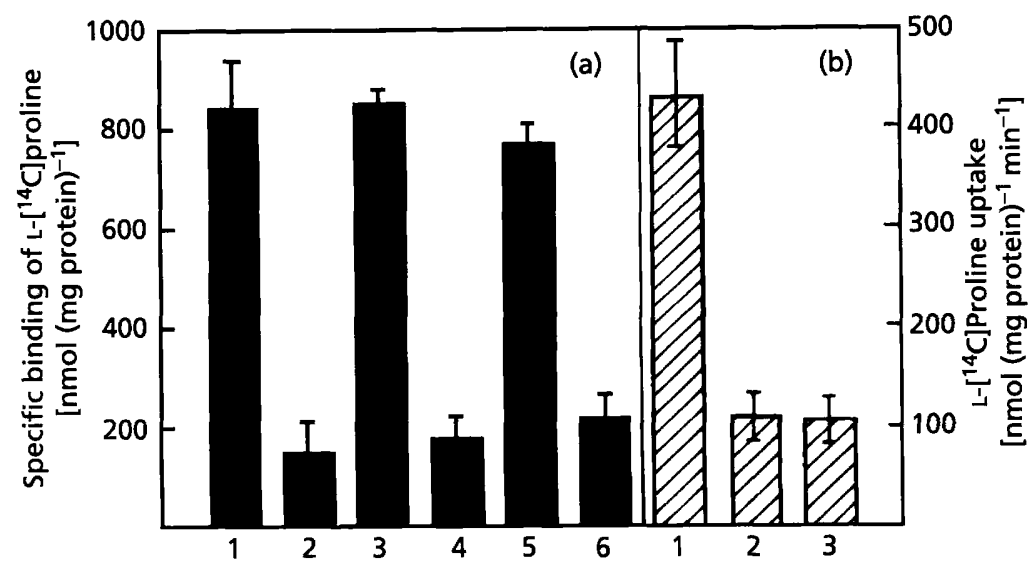

Fig. 3. Effect of NEM and cispentacin on Lproline binding and its translocation. (a) Specific binding of L-proline to the purified protein in the presence of NEM $(600 \mu \mathrm{M})$ and cispentacin (1 mM). 1, Control; 2 , in the presence of NEM; 3 , NEM addition after Lproline binding to the purified protein $(10 \mathrm{~min}) ; 4$, in the presence of cispentacin; 5 , cispentacin addition after L-proline binding to the purified protein $(10 \mathrm{~min}) ; 6$, L-proline addition after cispentacin binding to the purified protein. (b) Effect of NEM and cispentacin on L-proline uptake in the reconstituted purified protein in proteoliposomes. 1, Control; 2, in the presence of NEM; 3 , in the presence of cispentacin. L- $\left[{ }^{14} \mathrm{C}\right]$ Proline $\left(92.5 \mathrm{MBq} \mathrm{mmol}^{-1}\right)$ $(10 \mu \mathrm{M})$ was used for these experiments.

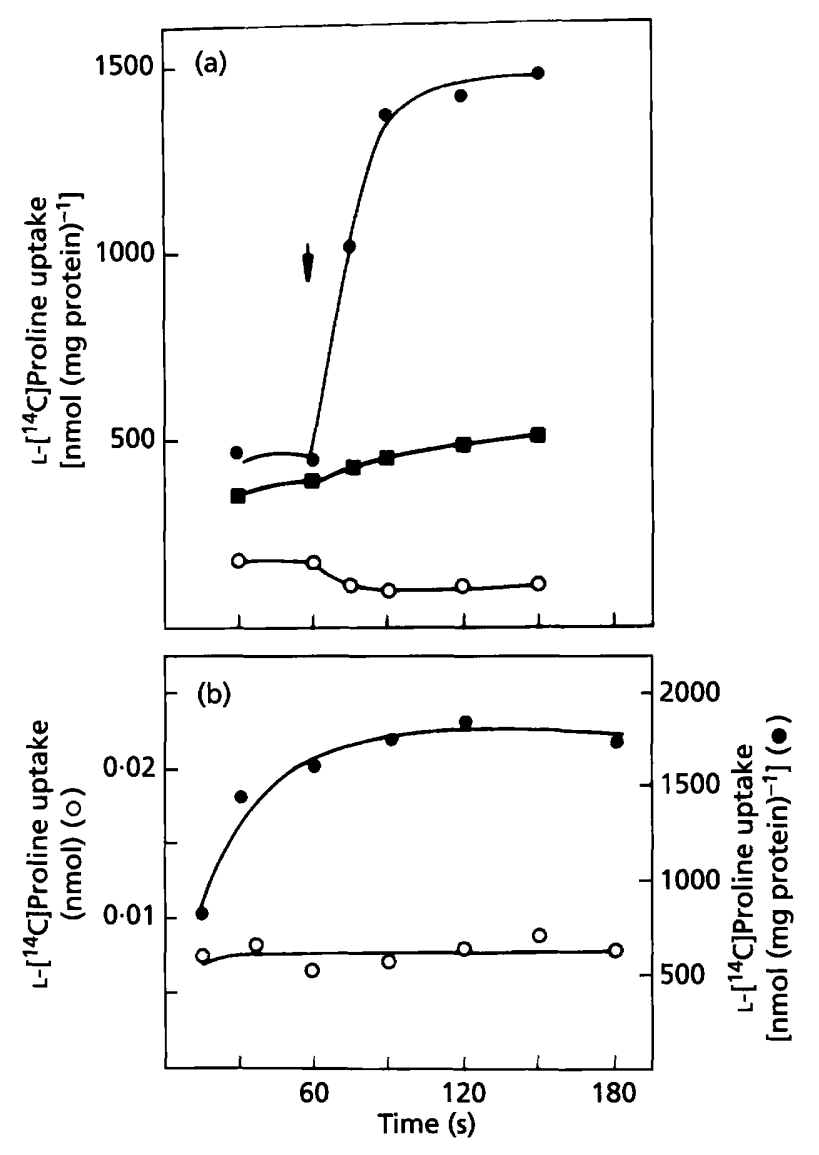

Fig. 4. L-Proline uptake in proteoliposomes reconstituted with the purified protein. (a) Uptake was initiated by the addition of $10 \mu \mathrm{M}$ valinomycin after $60 \mathrm{~s}$ as indicated by the arrow (O); 0 . uptake of L-proline in the absence of $\mathrm{K}^{+}$salt; $\mathbf{E}$, uptake of $\mathrm{L}$ proline in the presence of $25 \mu \mathrm{M} \mathrm{CCCP}$. (b) L-Proline uptake in the reconstituted proteoliposomes with $10 \mu \mathrm{M}$ valinomycin added from the start of the reaction (O) and L-proline uptake in the liposomes without reconstituting it with the purified protein (O).

Fig. 4(a) depicts a plot of a typical reconstitution experiment. The initial rate and maximum level of accumulation of proline were significantly increased when valinomycin was added after $60 \mathrm{~s}$ incubation. Valinomycin specifically increases membrane permeability for $\mathrm{K}^{+}$; consequently, due to the existing $\mathrm{K}^{+}$ gradient ( $25 \mathrm{mM} \mathrm{K}^{+}$inside, none added to the outside), a significant membrane potential $(\Delta \psi)$ is generated across the vesicular membrane (inside negative) which, in turn, drives the accumulation of L-proline (Hirata et al., 1971). Virtually no uptake of L-proline was observed when proteoliposomes were reconstituted without $\mathrm{K}^{+}$or when $\Delta \psi$ generated by the $\mathrm{K}^{+}$gradient was dissipated by an uncoupler, CCCP (Fig. 4a). When valinomycin was present in the uptake experiment from the beginning, the accumulation was immediate and it persisted over a period of several minutes. In the absence of the purified permease protein, no uptake into liposomes was seen, which again confirms the functionality of the reconstituted protein in proteoliposomes (Fig. 4b). The uptake of proline in reconstituted vesicles was maximal at pH 4.5 (Fig. 2d). The uptake could not be measured below $\mathrm{pH} 4.5$ since proteoliposomes tend to collapse beyond this $\mathrm{pH}$. It is pertinent to mention here that the uptake of L-proline in intact cells of C. albicans also showed an optimum $\mathrm{pH}$ between 4.5 and 5.5 (data not shown).

\section{Kinetics of L-proline uptake in proteoliposomes}

The kinetic parameters of the $\Delta \psi$-driven L-proline transport were assessed by measuring the initial velocities of uptake in the L-proline concentration range between 5 and $100 \mu \mathrm{M}$. The half-saturation constant $\left(K_{\mathrm{m}}\right)$ of $\mathrm{L}$-proline transport in the reconstituted system was $40 \mu \mathrm{M}$, which was in good agreement with that of the high-affinity component of proline transport $\left(K_{\mathrm{m}} 43 \mu \mathrm{M}\right.$ ) obtained from studies with intact cells (data not shown). To ascertain the specificity of proline permease in proteoliposomes, uptake was measured in the presence of excess concentrations (100-fold) of either unlabelled D-proline or L-proline analogues DHP and AZA. D-Proline was without any effect on L-proline accumulation whereas the other two analogues competitively inhibited L-proline uptake (Table 2). Similar results were obtained with the intact cells of $C$. albicans where L-proline uptake was competitively inhibited by 
DHP and AZA but remained unaffected by D-proline. Thus, the specificity of purified protein in reconstituted proteoliposomes was similar to that observed with intact cells (Table 2).

\section{Effect of NEM and cispentacin on L-proline uptake in reconstituted proteoliposomes}

Consistent with the binding results, NEM was also able to block the uptake of L-proline in reconstituted proteoliposomes (Fig. 3b). There was virtually no uptake of L-proline if NEM was added to proteoliposomes before energization was induced by the addition of valinomycin. Similarly, cispentacin also inhibited the uptake of L-proline in reconstituted proteoliposomes (Fig. 3b).

\section{DISCUSSION}

Despite the importance of nutrient transport in yeast, none of its transport proteins have been isolated and purified. This is largely due to the low content of the transport protein in the PM and partly because of the lack of a rapid assay to monitor purification. The present study describes for the first time the purification of the L-proline permease from C. albicans to homogeneity. The purified proline permease produced a single band of $67 \mathrm{kDa}$ by both native PAGE and Western blotting. The resolution by SDS-PAGE, however, showed two bands $(67$ and $64 \mathrm{kDa}$ ) of diffuse appearance. Since the molecular mass of the purified permease protein on a native gel was $67 \mathrm{kDa}$, the possibility of two subunits being resolved by SDS-PAGE was excluded. Recently, a maltose transport protein was identified in S. cerevisiae which also gave two bands on SDS-PAGE (Van den Broek et al., 1994). Although the proteins of the two bands differed in size, their sequence analysis revealed them to be homologous and highly hydrophobic. The antibodies against the $\mathrm{Hxt} 2$ glucose transporter also gave two bands on SDS-PAGE even after the blockage of glycosylation by tunicamycin (Wendell \& Bisson, 1993). It appears from our results, as well as those of others, that the heterogeneity in size could be common among hydrophobic transport proteins of yeasts due to their interaction with SDS (Bernardo et al., 1994; Isambert et al., 1992). In this regard, it must be mentioned that no difference between the two bands of proline permease on SDS-PAGE was detected when stained for glycosylation (data not shown), thus excluding the heterogeneous glycosylation of the two bands as the reason for the appearance of the doublet.

The molecular mass of the purified protein was similar to that deduced from the nucleotide sequence of PUT4 (proline permease) of $S$. cerevisiae (Vandenbol et al., 1989). The size of the purified protein $(67 \mathrm{kDa})$ obtained on a gradient gel, its binding specificity as well as its translocation properties in reconstituted proteoliposomes, are in agreement that the purified protein is a C. albicans proline permease.
Similarly to the C. albicans permease, the proline transporter of Escherichia coli in reconstituted vesicles has also been shown to be sensitive to NEM (Hanada $e t$ al., 1992). NEM is able to inhibit proline binding and its subsequent translocation but its effect could be prevented if L-proline binding precedes NEM addition. Thus a cysteine residue(s) close to the binding site is probably essential for the proline permease activity of $C$. albicans.

The L-proline accumulation in the reconstituted proteoliposomes reported in this paper was energized by the membrane potential generated by the valinomycininduced flux of $\mathrm{K}^{+}$out of the proteoliposomes. However, we were unable to energize L-proline accumulation by an applied $\mathrm{pH}$ gradient. This was very likely due to the nonspecific membrane permeability for protons leading to $\mathrm{H}^{+}$-equilibration before $\mathrm{L}$-proline accumulation could be started (Mair \& Höfer, 1988; Höfer et al., 1991).

Cispentacin inhibits homoserine dehydrogenase and interferes with the synthesis of amino acids of the aspartate family. Since this enzyme is absent in animals, the drug can selectively kill prototrophic fungi (Yamaki et al., 1990; Georgopapadokou \& Walsh, 1994). The interaction of cispentacin with purified proline permease protein confirms that the drug competitively inhibits the binding and translocation of L-proline. Thus, knowledge of the transport mechanism of the drug and of its interaction with the purified protein would help in designing better synthetic drugs.

\section{ACKNOWLEDGEMENTS}

We thank Abbott Laboratories, Chicago, USA, for providing us with the drug cispentacin for this work. One of us (D. J.) sincerely thanks Deutscher Akademischer Austauschdienst (DAAD) for a short-term scholarship to carry out part of the reconstitution experiments at the Botanisches Institut, Universität Bonn, Germany. D.J. also gratefully acknowledges the Junior and Senior Research Fellowships awarded by the University Grants Commission (UGC). This work was supported in part by the Department of Science and Technology, New Delhi (SP/SO/DO2/94) and by the Deutsche Forschungsgemeinschaft (grant no. 40555).

\section{REFERENCES}

Bernardo, A. A., Kear, F. T., Ruiz, O. S. \& Arruda, J. A. L. (1994). Renal cortical basolateral $\mathrm{Na}^{+} / \mathrm{HCO}_{3}^{-}$co-transport: partial purification and reconstitution. J Membr Biol 140, 31-37.

Blum, H., Bier, N. \& Gros, N. J. (1987). Improved silver staining of plant protein, RNA and DNA in polyacrylamide gel. Electrophoresis 8, 93-99.

Bradford, M. M. (1976). A rapid and sensitive method for the quantitation of proteins utilizing the principle of protein-dye binding. Anal Biochem 72, 248-254.

Capobianco, J. O., Zakula, D., Coen, M. L. \& Goldman, R. C. (1993). Anti-Candida activity of cispentacin: the active transport of amino acid permeases and its possible mechanism of action. Biochem Biophys Res Commun 190, 1037-1044.

Catty, D. \& Raykundalia, C. (1988). Gel immunodiffusion, immunoelectrophoresis and immunostaining methods. In Anti- 
bodies: a Practical Approach, vol. 1, pp. 137-167. Edited by D. Catty. Oxford: IRL Press.

Cooper, T. G. (1982). Transport in Saccharomyces cerevisiae. In Molecular Biology of the Yeast Saccharomyces: Metabolism and Gene Expression, pp. 399-461. Edited by J. N. Strathern, E. M. Jones \& J. R. Broach. Cold Spring Harbor, NY: Cold Spring Harbor Laboratory.

Dabrowa, N. \& Howard, D. H. (1981). Proline uptake in Candida albicans. J Gen Microbiol 127, 391-397.

Georgopapadokou, N. H. \& Walsh, T. J. (1994). Human mycoses : drugs and targets for emerging pathogens. Science 264, 371-373.

Grenson, M., Hou, C. \& Crabeel, M. (1970). Multiplicity of the amino acid permease in Saccharomyces cerevisiae. J Bacteriol $103,770-774$.

Gupta, P., Mahanty, S. K., Ansari, S. \& Prasad, R. (1991). Isolation, purification and kinetic characterisation of the plasma membrane $\mathrm{H}^{+}$-ATPase of Candida albicans. Biochem Int 24, 907-915.

Hanada, K., Yoshida, T., Yamato, I. \& Anraku, Y. (1992). Sodium ion and proline binding sites in the $\mathrm{Na}^{+}$/proline symport carrier of Escherichia coli. Biochim Biophys Acta 1105, 61-66.

Hirata, H., Alterdorf, K. \& Harold, F. M. (1971). Role of an electrical potential in the coupling of metabolic energy of active transport by membrane vesicles of Escherichia coli. Proc Natl Acad Sci USA 70, 1804-1806.

Höfer, M., Mair, T. \& Wernsdorfer, E. (1991). Reconstituted plasma membrane vesicles: a tool to study transport in yeast. In Yeast: Molecular Biology and Biotechnology, pp. 239-253. Edited by R. Prasad. New Delhi: Omega Scientific.

Holmes, A. R. \& Shepherd, M. G. (1987). Proline-induced germtube formation in Candida albicans: role of proline uptake and nitrogen metabolism. J Gen Microbiol 133, 3219-3228.

Hubbard, M. J., Surarit, R., Sullivan, P. A. \& Shepherd, M. G. (1986). The isolation of plasma membrane and characterisation of plasma membrane ATPase from the yeast Candida albicans. Eur J Biochem 154, 375-381.

Isambert, M. F., Gasnier, B., Botton, D. \& Henry, J.-P. (1992). Characterisation and purification of the monoamine transporter of bovine chromaffin granules. Biochemistry 31, 1980-1986.

Jayakumar, A., Singh, M. \& Prasad, R. (1978). Characteristics of proline transport in normal and starved cells of Candida albicans. Biochim Biophys Acta 514, 348-355.

Jayakumar, A., Singh, M. \& Prasad, R. (1979). An inducible proline transport system in Candida albicans. Biochim Biophys Acta 556, 144-150.

Jayakumar, A., Singh, M., Verma, R. S., Baquer, N. Z. \& Prasad, R. (1981). Characteristics of proline transport in the spheroplasts isolated from Candida albicans. Indian J Biochem Biophys 18, 206-210.

Laemmli, U. K. (1970). Cleavage of structural proteins during the assembly of the head of bacteriophage T4. Nature 277, 680-685.

Lasko, P. F. L. \& Brandriss, M. C. (1981). Proline transport in Saccharomyces cerevisiae. J Bacteriol 148, 241-247.

Mair, T. \& Hofer, M. (1988). ATP-induced generation of $\mathrm{pH}$ gradient and/or membrane potential in reconstituted plasma membrane vesicles from Schizosaccharomyces pombe. Biochem Int 17, 593-604.

Naider, F. \& Becker, J. M. (1990). Peptide transport in Candida albicans. In Peptide Transport, pp. 170-198. Edited by M. R. MacGinnis. Heidelberg: Springer-Verlag.
O'Farrel, P. H. (1975). High resolution two-dimensional electrophoresis of proteins. J Biol Chem 250, 4007-4021.

Odds, F. C. (1988). Biological aspects of pathogenic Candida species. In Candida and Candidosis: a Review and Bibliography, 2nd edn, pp. 42-59. Edited by F. C. Odds. London: Baillière Tindall.

Payne, J. W. \& Shallow, D. A. (1985). Studies on drug targeting in the pathogenic fungus Candida albicans: peptide transport mutants resistant to polyoxin, nikkomycin and basilysin. FEMS Microbiol Lett 28, 55-60.

Prasad, R. \& Hઠfer, M. (1987). The electrochemical gradient of $\mathrm{H}^{+}$ in Candida albicans and its relevance to the uptake of nutrients. Biochem Int 154, 375-381.

Prasad, R. (1987). Nutrient transport in Candida albicans, a pathogenic yeast. Yeast 3, 209-221.

Rao, L. R. S., Prasad, D. S. \& Prasad, R. (1986). Transport of basic amino acids in Candida albicans. Biochim Biophys Acta 856, 237-243.

Schmidt, A., Hall, M. N. \& Koller, A. (1994). Two FK 506 resistanceconferring genes in Saccharomyces cerevisiae, TAT1 and TAT2: encodes amino acid permease mediating tyrosine and tryptophan uptake. Mol Cell Biol 14, 6597-6606.

Serrano, R. (1988). $\mathrm{H}^{+}$-ATPase from plasma membranes of Saccharomyces cerevisiae and Avena sativa roots: purification and reconstitution. Methods Enzymol 157, 533-544.

Shepherd, M. G. (1991). Morphogenesis in Candida albicans. In Candida albicans: Cellular and Molecular Biology, pp. 5-19. Edited by R. Prasad. Heidelberg: Springer-Verlag.

Sychrová, H. \& Chevallier, M. R. (1993). Transport properties of a C. albicans amino acid permease whose putative gene was cloned and expressed in S. cerevisiae. Curr Genet 24, 487-490.

Sychrová, H. \& Souciet, J.-L. (1994). CAN1, a gene encoding a permease for basic amino acids in Candida albicans. Yeast 10, 1647-1651.

Van den Broek, P. J. A., Van Leeuwen, C. C. M., Weusthuis, R. A., Postma, E., Van Dijken, J. P., Karssies, R. H. \& Amons, R. (1994). Identification of the maltose transport protein of Saccharomyces cerevisiae. Biochem Biophys Res Commun 200, 45-51.

Vandenbol, M., Jauniaux, J.-C. \& Grenson, M. (1989). Nucleotide sequence of the Saccharomyces cerevisiae PUT4 proline permease encoding gene: similarities between CAN1, HIP1 and PUT4 permeases. Gene 83, 153-159.

Wach, A., Ahlers, J. \& Graber, P. (1990). The $\mathrm{H}^{+}$-ATPase of the plasma membrane from yeast. Kinetics of ATP hydrolysis in native membranes, isolated and reconstituted enzymes. Eur $J$ Biochem 189, 675-682.

Wendell, D. L. \& Bisson, L. F. (1993). Physiological characterisation of putative high-affinity glucose transporter $\mathrm{Hxt2}$ of Saccharomyces cerevisiae by use of anti-synthetic peptide antibodies. J Bacteriol 175, 7689-7696.

Yamaki, H., Yamaguchi, M., Imamura, H., Suzuki, H., Nishimura, T., Saito, H. \& Yamaguchi, H. (1990). The mechanism of antifungal action of (s)-2-amino-4-oxo-5-hydroxypentanoic acid, RI-331: the inhibition of homoserine dehydrogenase on Saccharomyces cerevisiae. Biochem Biophys Res Commun 168, 837-843.

Received 9 July 1996; revised 14 October 1996; accepted 7 November 1996. 